Arab World English Journal (AWEJ) Volume 12. Number3 September 2021

DOI: https://dx.doi.org/10.24093/awej/vol12no3.32

\title{
An Exploratory Study of EFL Teachers' Assessment Conceptions at a Saudi University
}

\author{
Ahmad Qadi \\ English language and Translation \\ Umm Alqura University, Makkah, Saudi Arabia \\ Email: ahqadi@uqu.edu.sa
}

Received: 6/21/2021

Accepted: 9/1/2021

Published: 9/29/2021

\begin{abstract}
Each teacher evaluates students' learning outcomes in their own way, depending on their own ideas and beliefs about teaching, learning, and assessing. It impacts on how pupils work. As a result, concentrating on instructors' perspectives in general appears to be vital, and exposing EFL teachers' evaluation concepts is crucial and requires considerable investigation. The current study examines teachers' assessment conceptions of English as a foreign language (EFL) at a Saudi University. Specifically, it investigates EFL university teachers' assessment conceptions using Brown's (2006) Teachers' Conceptions of Assessment Abridged Inventory, four-factor assessment inventory conceptions that include variables like student accountability, school accountability, progress, and irrelevance. The survey employed a Likert scale with response options ranging from one (strongly disagree) to five (strongly agree). The researcher gathered the study's data using Google Forms and administered an online questionnaire to fifteen EFL English teachers in English Language Center at a Saudi University called Afaq University (pseudonym), Saudi Arabia. The obtained quantitative data were analyzed manually by descriptive statistics. The findings demonstrated that of all participants, the enhancement principle had the primary value, whereas the conceptions of irrelevance, on the other hand, were discovered to have the lowest level of agreement. The study presented some pedagogical implications and then concluded with the need for further triangulated exploration of the phenomenon.
\end{abstract}

Keywords: Classroom assessment, conceptions of assessment, teachers' beliefs,

Cite as: Qadi, A. (2021). An Exploratory Study of EFL Teachers' Assessment Conceptions at a Saudi University. Arab World English Journal, 12 (3) 464-485.

DOI: https://dx.doi.org/10.24093/awej/vol12no3.32 


\section{Introduction}

In education, assessment is enormously essential, and the educationists define it as the process of identifying, evaluating, analysing, and applying the information to determine students' learning and development (Erwin, 1991). Classroom evaluation necessitates a significant amount of time and energy; teachers can dedicate up to $40 \%$ of their time to activities related to assessment (Stiggins, 1988). Educationists use assessment to gather information necessary for making educational decisions. As Danielson (2008) points out that assessment is crucial in the development of educational policies. It aims to assess students' effectiveness and provide input on the structure and enhancement of instructional programs.

Assessment knowledge serves as the foundation for assessment conception, a term coined by Brown (2004), which aims to expose the intent of performing assessment practices into four categories: improvement, school accountability, student accountability, and irrelevance. Assessment, according to the improvement conception, aims at enhancing the quality and quantity of learning. Assessment, according to school accountability, is used to evaluate a school's achievement. Student accountability asserts that institutions undertake checks to monitor students' progress in their studies, and eventually, irrelevance conceptions maintain that assessments are pointless and ineffective.

This concept aids educators in planning, monitoring, and evaluating students' learning. Material selection, classroom activity selection, monitoring and assessing students' learning, providing feedback, and improving the teaching process are just a few of the many tasks that educators need to accomplish. Analysing educators' perspectives on evaluation is one step in gaining a better understanding of how education works. Unfortunately, only a few researchers have conducted studies to investigate teachers' perspectives on assessment in the Saudi context in general and in EFL teachers at English Language Center, Afaq University in particular.

\section{Research problem}

Assessment is a critical component of education, so putting it into practice can be demanding. According to Stiggins (1988), classroom assessment takes almost half of a teacher's time to plan and conduct. Even though assessment is joint, it lacks clear rules and boundaries for practitioners to benefit from, making it a challenging task. Teachers, on the other hand, have not been prepared or trained for such a role. The beliefs and practices of teachers have a significant impact on how educationists use evaluation methods. Pajares (1992) intertwined beliefs and actions because he considered teachers' conceptions influenced their instructional practices. According to Gore, Griffiths and Ladwig (2006), practitioners' beliefs shape their preferences much more powerfully and effectively than their school experience and context. As a result, figuring out what they believe is essential to tailor their wisdom to educational policies and requirements. Even though most researchers researched evaluation concepts internationally, we find a scarcity of such research in Saudi Arabia in general and the English Language Center, Afaq University, in particular. As a result, exploring EFL teachers' evaluation views in the present context identifies perceptions efficiently that significantly impact their assessment practices. 


\section{The rationale of the study}

According to Brown (2008), people's views and the standards of their social environment tend to play a significant role in establishing their style of actions and practices. Teachers' conceptions are critical in the monitoring and evaluation of curriculum and instruction. Every teacher assesses students' learning outcomes uniquely, based on their thoughts and perceptions about teaching, learning, and evaluating. It influences how students work. As a result, focusing on teachers' views, in general, appears to be very important, and disclosing EFL teachers' assessment conceptions is crucially significant and necessitates extensive research.

\section{Significance of the study}

Educationists commonly use assessment methods at all levels of education, but practitioners' viewpoints have been neglected or understudied to this point. Exploring and revealing EFL teacher conceptions of assessment, its types, and concepts in Saudi Arabia in general and English Language Center, Afaq University in particular, may help us ascertain the rationale behind assessment practices and procedures adopted in the Saudi educational context.

\section{Research question}

The researcher developed the following research question to help conduct the study:

- What are the assessment conceptions of EFL teachers at the English Language Center, Afaq University, Saudi Arabia?

To answer the given research question, the study set the following research objective ;

- To explore the conceptions of assessment among EFL Teachers at English Language Center, Afaq University, Saudi Arabia.

\section{Review of Related Literature}

This segment introduces assessment before delving into the principle of assessment and its four main parameters.

\section{Assessment}

Black and William (1998) considered that "assessment refers to all those activities undertaken by teachers, and by the students in assessing themselves, which provide information to be used as feedback to modify the teaching and learning activities in which they are engaged" (p. 2).

Gonzales (2003) has viewed assessment as "a systematic gathering of information about student's performance that enables teachers to monitor their learning" (p.89). According to Badders (2000), it is mandatory to apply various forms of assessments to collect different categories of information about students to evaluate a range of aspects of their learning, conceptual progress, and competence development and implementation.

Assessment can perform a variety of functions. To Trotter (2006), "assessment can be used to provide motivation. Strategies for modifying the assessment system that can influence students' approaches include integrating assessment into the learning process, so assessment is the total learning experience" (p. 508). According to Opre (2015), it aids the educational 
system by providing information about students' learning processes, teachers' instructional activities, the program, and accountability. Assessment has a significant impact on how students learn.

\section{Conceptions of Assessment}

People's thoughts, attitudes, and actions are all influenced by their concepts. Teachers' conceptions and values have a significant impact on the teaching and learning process. According to Harris and Brown (2009), teachers' conceptions of evaluation are substantial because they influence their evaluation practices. Therefore, it is essential to comprehend teachers' thoughts on evaluation and its practice in their educational contexts. Teachers' methods for evaluating student results differ depending on their vocabulary, evaluation, learning, and teaching (Moiinvaziri, 2015). As a result, it is critical to pay close attention to their views (about evaluation) to comprehend their practices fully and identify potential reforms in assessment practices. Brown $(2004,2006)$ created and tested four-factor the Conception of Assessment (COA-III) instrument to evaluate teachers' perceptions of assessment. Brown based the COA-III on existing literature to explain the assessment's objectives, which he categorised as under:

\section{Improvement Conception}

According to Brown (2004), the core principle of this viewpoint is that evaluation guides the development of students' learning and teaching performance. Students should certify their learning outcomes and improve their learning outcomes through assessment; therefore, educationists must interpret assessment in ways that enhance students' learning outcomes (Brown, 2006).

\section{Student Accountability}

For a long, assessment has been acknowledged and applied as a summative or formative assessment of learning, primarily focusing on evaluating students' learning outcomes and possible learnings. According to Brown (2004), students' evaluation accountability implies their accountability for their education. In a nutshell, it refers to how educationists use evaluation to measure students' success against pre-determined parameters (Moiinvaziri, 2015). According to Brown (2004), more significant outcomes such as graduation or placement and being officially reported as having achieved a certain rank, grade, or score are the main concerns of a student's accountability conception.

\section{School Accountability}

Moiinvaziri (2015) perceives school accountability as the use of assessment to determine the performance level of teachers or schools concerning specified expectations. Brown (2004) focuses on two aspects of school accountability: demonstrating instructional competence and enhancing educational performance. Similarly, school accountability can serve as a springboard for improving the effectiveness of teaching methodologies, allowing students to advance to higher levels of education and have a better understanding of their accomplishments (Brown \& Abeywicrama 2010).

\section{The Irrelevance Conception}

According to Brown (2004), In the educational context, the term "irrelevance" means 
that assessment has no role or benefits and that when applied, it adversely affects pupils, teachers, and all stakeholders. The fourth conception of evaluation is based on the premise that assessment, typically described as a standardised, structured method of assessing student performance, should be dismissed for its inherent counter-productivity-invalidity, meaninglessness that may negatively influence teachers' pupils, curriculum, and instruction. According to Harris and Brown (2009), teachers' discretion and specific competence for the sole purpose of teaching are compromised by evaluation, so teachers' intuition should be valued rather than systematically evaluating students' results.

\section{Assessment Conception Research Studies}

A plethora of researchers investigated to reveal various assessment purposes in multiple cultures and contexts.

Brown (2004) surveyed New Zealand of 525 teachers and managers. With 50 items (COA- III), he tried to evaluate four critical objectives of assessment (COA- III). He found that the respondents believed in the principle of school accountability and that, apart from their irrelevance, all three objectives are significantly correlated.

Li and Hui (2008) investigated assessment conceptions regarding 97 vocational and technical college lecturers in Hangzhou, Mainland China. The results indicated that they agreed that evaluation increases teaching and student learning while also increasing school accountability. On the other hand, the lecturers were sceptical that evaluation, as opposed to passing exams, could provide accurate information about deep learning.

In the context of Hong Kong, Brown, Kennedy, Fok, Chan, and Yu, (2009) examined the perspectives of 300 teachers from 14 schools in Hong Kong by administering Chinese translation of the "Teacher's Conception of Assessment" and "Practices of Assessment" inventories. The researcher finds the results to be specifically related to the use of assessment to improve instruction. These findings imply that broader Chinese cultural norms about exams are embedded in school culture and may impede the appraisal reform policy in Hong Kong.

Vardar (2010) explored the assessment conceptions of 414 Turkish teachers teaching various subjects at various grade levels, intending to determine any variations in teachers' assessment conceptions based on their academic establishment. In-service training years of professional experience, teaching subject, according to the correlation findings, progress conceptions, accountability of students and schools were all moderately associated. The conception of irrelevance, on the other hand, had no significant relationship with different concepts. The findings also revealed that teachers with prior teaching experience and those who graduated from undergraduates differed significantly.

Brown and Michaelides (2010) sampled 249 Greek-Cypriot teachers using a Greek translation of the TCOA inventory. The mean score differed minimally for two improvementoriented concepts, moderately for poor evaluation and highly for school accountability and overlooking evaluation variables. Conceptional similarities and differences appear to reflect common beliefs. Differences and similarities in concepts indicate dissimilarities and commonalities in educational policy and practice. 
Brown and Remesal (2012) assessed the responses of two classes of prospective teachers (New Zealand (324) and Spain (672) using the TCOA inventory. The meaning and intent of assessment are significant to future teachers because (a) Most educational evaluations are completed in classrooms, and (b) potential teachers have comprehensive prior school evaluation experience. The findings revealed that prospective teachers' responses vary from current teachers' responses due to a lack of teaching experience.

In an Iranian background, Moiinvaziri (2015) examined 147 university teachers' conceptions of assessment using the short version of Teachers' Conceptions of Assessment (TCA) inventory (Brown, 2006). The findings revealed that most teachers believed in user testing to enhance teaching and learning. Teachers did not vary in their views based on their ethnicity, even though there was a connection between teaching experience and teachers' evaluation perceptions.

In an Indonesian background, Azis (2015) studied the assessment conceptions of 107 English junior high teachers. According to the findings, the researcher offered a questionnaire and semi-structured interviews to participants in his mixed-method analysis. Participants thought the assessment aimed to enhance teachers' teaching and students' learning, assessment, according to the participants in this report, is used to enhance teaching and learning and show student and school responsibility. They appeared to disagree with those who claim the judgement is unimportant.

Barnes, Fives, and Dacey (2017) examined the perspectives of 179 K-12 teachers on assessment purposes. Through Conceptions of Assessment Instrument. Teachers believed assessment is both valid for accountability and appropriate for informing teaching and learning. Furthermore, they also discovered that teachers have multiple, often contradictory views about evaluation, which can affect their ability to participate in ongoing professional knowledge on the subject and their involvement with various assessment activities.

In Egypt's high-stakes, test-driven environment, Gebril (2016) explored the assessment conceptions of 170 English teachers, both pre-service and in-service, through an assessment conceptions questionnaire. The study's findings revealed that in-service teachers supported the evaluation enhancement feature more than pre-service teachers. The results provide a variety of implications for language instructors, teacher educators, and policymakers. The efficacy of teacher training programs was viewed as ineffective by both groups.

In another study, Brown and Remesal (2017) conducted two surveys with 566 Ecuadorian schoolteachers. After a few modifications, the results revealed that the Spanish and New Zealand models matched the data. The improvement, caution, and social regulation variables had the highest mean scores, whereas revision, caution, and social control factors received the highest average ratings. These findings are in line with teachers' perceptions of evaluation in the context of solid test systems.

In the Turkish context, Yetkin (2018) probed assessment conceptions of 204 prospective teachers. According to descriptive statistics, the concept of improvement was the most important, while the idea of irrelevance was the least important. The concepts of 
improvement and accountability at the school and student levels were significantly linked, whereas improvement and irrelevance conceptions were negatively linked.

Mustafa and Manaf (2019) explored MARA Professional College lecturers' ( $\mathrm{N}=50)$ student assessment and practices conceptions. The descriptive quantitative approach analysed the lecturers' perceptions of student assessment in terms of development, accountability at the school level and the students' level and irrelevance, and the relationships between these perceptions. According to the results, growing teachers' evaluation awareness has a considerable effect on their assessment practices. To strengthen evaluation preparation, related organisations should work together.

Yetkin and Ozer (2020) studied the perspectives of 97 pre-service and in-service English teachers on assessment. Descriptive findings revealed that conception of improvement had the highest degree of agreement among participants. School responsibility, on the other hand, received the least amount of support. According to the correlation findings, there was a significant relationship between improvement, student accountability, and school accountability. Fourth graders had the highest mean value for student accountability, while teachers had the highest mean value for school accountability.

After the thorough perusal of the related literature, the researcher has identified the scarcity of such research in the context of Saudi EFL Teachers in general and in the context of the English Language Center, Afaq University in particular. Analysing educators' perspectives on evaluation is one step in gaining a better understanding of how education works.

\section{Method}

The current analysis uses a quantitative research design and an online survey tool to analyse EFL teachers' conceptions of assessment. In this case, the researcher collects data through a Teacher's Conception of Assessment (TCOA-IIIA- Version 3- Abridged scale of 27 items).

\section{Participants}

The current study employed convenience sampling, which is defined as a type of nonprobability sampling through which researchers obtain research data from a pool of respondents that is readily available. It is the most used sample technique because it is incredibly efficient, uncomplicated, and economical. The researcher administered the survey questionnaires to all male faculty members, but only fifteen EFL Teachers responded to the online survey questionnaire.

The researcher conducted the present study at Afaq Qura University's English Language Center in Saudi Arabia. The English Language Center has a distinguished history. It started in 1990 and offered preparatory language courses for elementary, intermediate, and advanced level students for multinational and multicultural students. The researcher himself has been part of the faculty since 2000. Due to having a direct influence on teachers' behaviour to a high degree, the researcher thought it worth exploring the conceptions of fellow teachers about assessment, both for current understanding and prospective implementations. 


\section{Research Instruments}

In the current study, the researcher has used the instrument developed by Brown (2006) entitled Teachers' Conceptions of Assessment Inventory-Abridged (TCA-IIIA Version 3- Abridged) to evaluate teachers' perceptions of assessment intent. It is a reliable indicator of teachers' evaluation conceptions and can help in assessment-related teacher career development and testing projects (Brown, 2006). Brown used the CoA-III inventory in various countries, including India, Hong Kong, Spain, China, New Zealand, the Netherlands and Queensland (Australia), to explore teachers' perspectives on evaluation in multiple cultural contexts (Barnes et al., 2017). The abridged inventory TCoA-IIIA-Version 3 contains four variables and 27 items or indicators, which Brown ( ) divided into four categories: conception of improvement (twelve), the concept of school accountability (three), the conception of student accountability (three), and conception of irrelevance (nine). The researcher used a Likert scale of 1 (strongly disagree) to 5 (strongly agree) in the survey. The more they valued an object, the more they agreed with that statement or degree of agreement regarding their assessment beliefs.

\section{Pilot Study}

A pilot study was performed with colleagues to ensure the questionnaire's validity, reliability, and usability, and the researcher made some changes and improvements based on their feedback.

\section{Data Collection Procedures}

The researcher obtained the data from English Language Center during the spring semester of the 2020 academic year. The researcher approached the participants by phone before the survey and informed them of the study's goals, brief details about the forms, and the confidentiality of their responses. The data-processing time varied from one to five days. Following data collection, each instructor was reassured of confidentiality and thanked for their cooperation.

\section{Data Analysis}

The researcher displayed the inventory data using pie charts and bar charts and employed descriptive statistics to examine the results.

\section{Results}

There are two sections of this segment. In the first segment, the researcher provides the participants' demographic details, whereas, in the second section, the describes the findings of the TCoA-111 inventory concerning four variables in teachers' assessment conceptions.

\section{Demographic Information}

Experience in teaching

15 responses

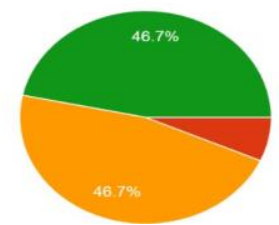

1-5 years

$11-15$ years

16-20 and above

Figure 1.Experience in teaching 
Educational Level

15 responses

Figure 2. Educational level

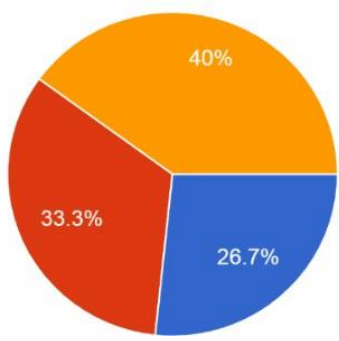

Professional training in ELT

15 responses

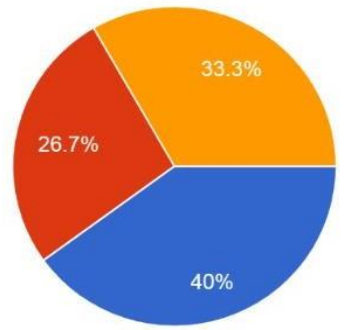

Figure 3. Professional training in ELT

The demographic information shows that most of the teachers, almost $93 \%$ have more than ten years' experience in teaching, with $40 \%$ having a PhD degree and 33\% having an M.Phil. and $26 \%$ have only M.A. degree, but interestingly, all the teachers have acquired professional training in ELT.I

\section{Teachers' Conceptions of Assessment}

\section{Improvement Conception}

3)Assessment is a way to determine how much students have learned from teaching.

15 responses

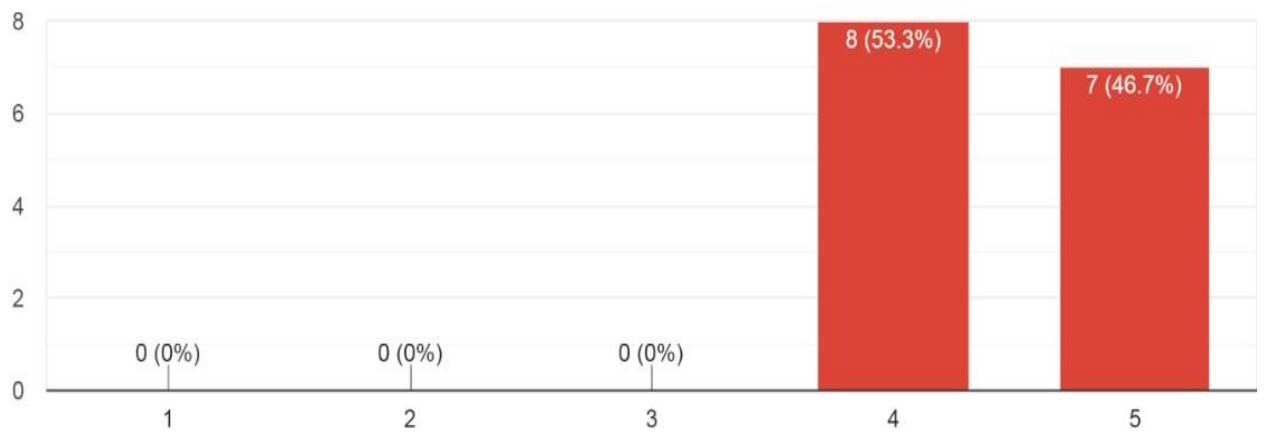

Figure 4. Determining students' learning from teaching 
Arab World English Journal (AWEJ) Volume 12. Number 3. September 2021

An Exploratory Study of EFL Teachers' Assessment Conceptions

Qadi

4)An assessment provides feedback to students about their performance.

15 responses

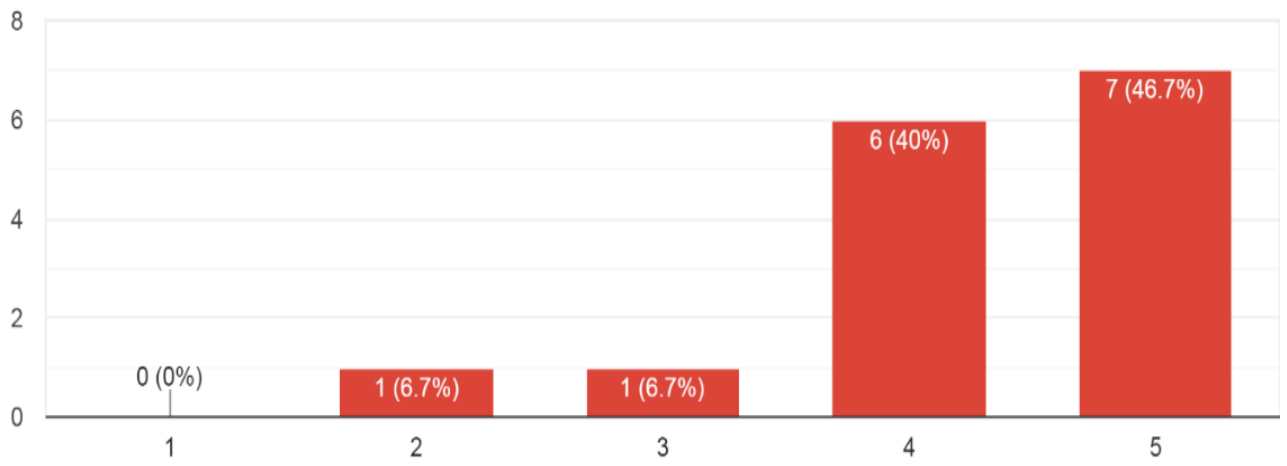

Figure 5. Feedback to students about their performance

5)Assessment is integrated with teaching practice.

15 responses

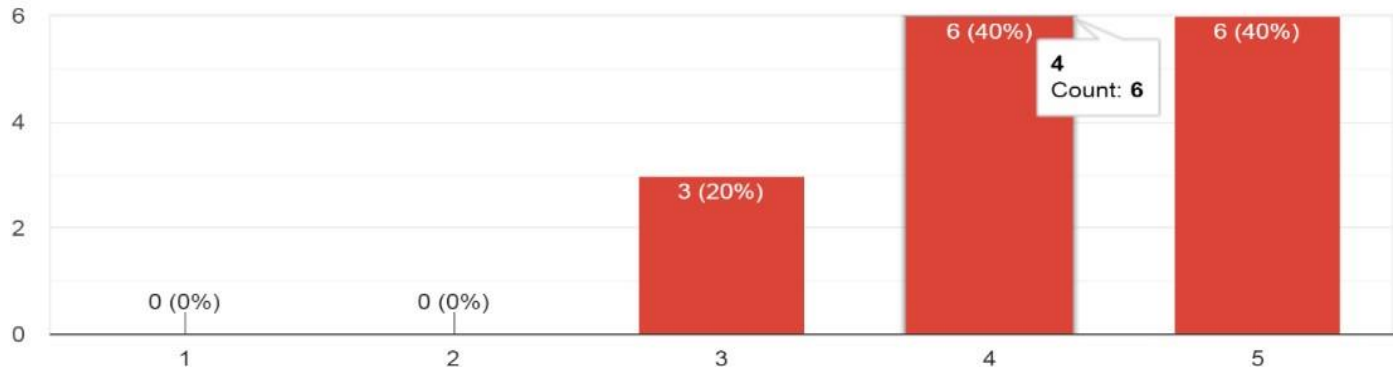

Figure 6. Integration of assessment with teaching practice.

6)Assessment results are trustworthy

15 responses

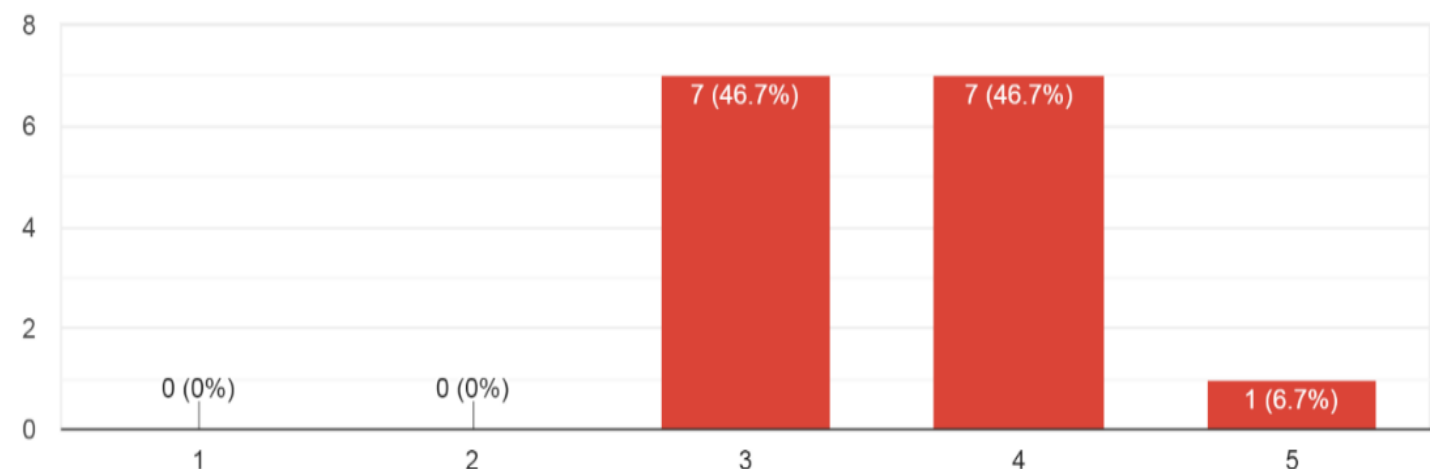

Figure 7. are the trustworthiness of assessment results. 
Arab World English Journal (AWEJ) Volume 12. Number 3. September 2021

An Exploratory Study of EFL Teachers' Assessment Conceptions

Qadi

12) Assessment establishes what students have learned.

15 responses

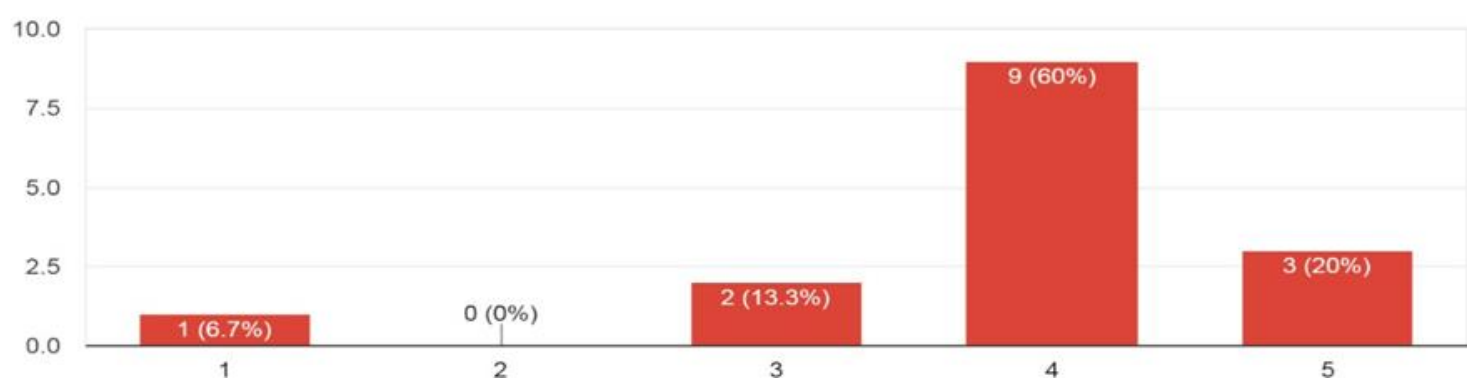

Figure 8. Establishing students learning

13) Assessment feeds back to students their learning needs.

15 responses

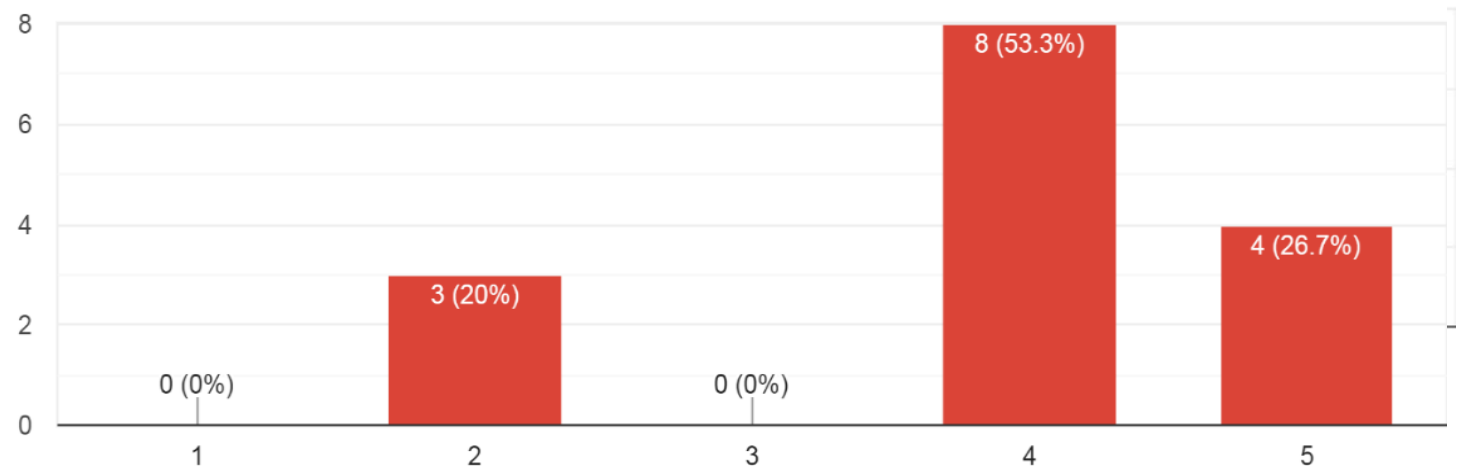

Figure 9. Provision of feedback to students their learning needs

14) Assessment information modifies ongoing teaching of students 15 responses

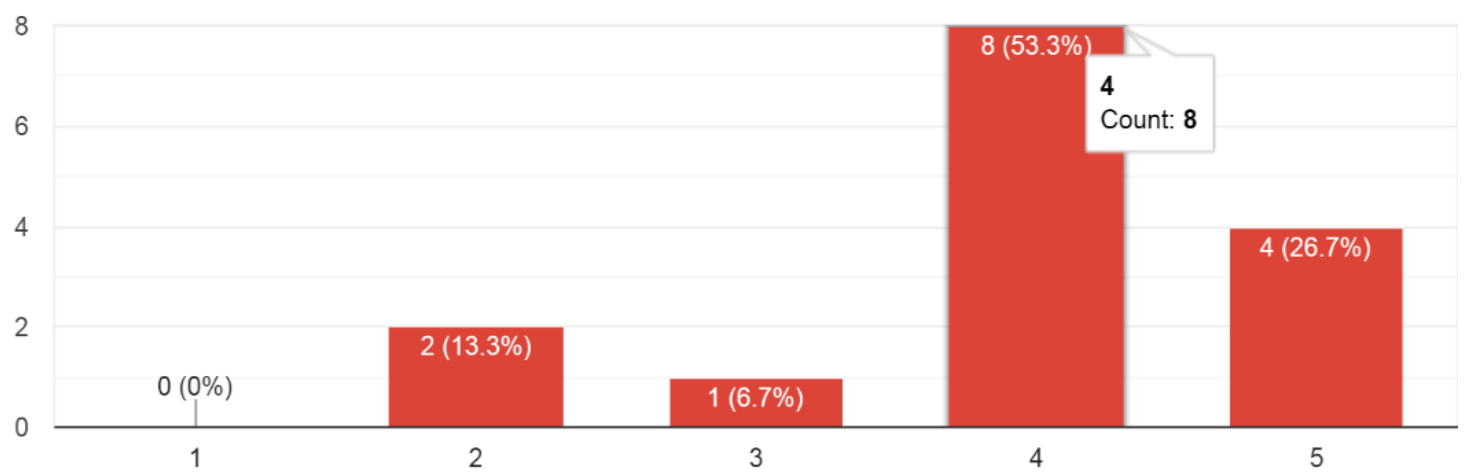

Figure 10. Modification in ongoing teaching of students 
15) Assessment results are consistent

15 responses

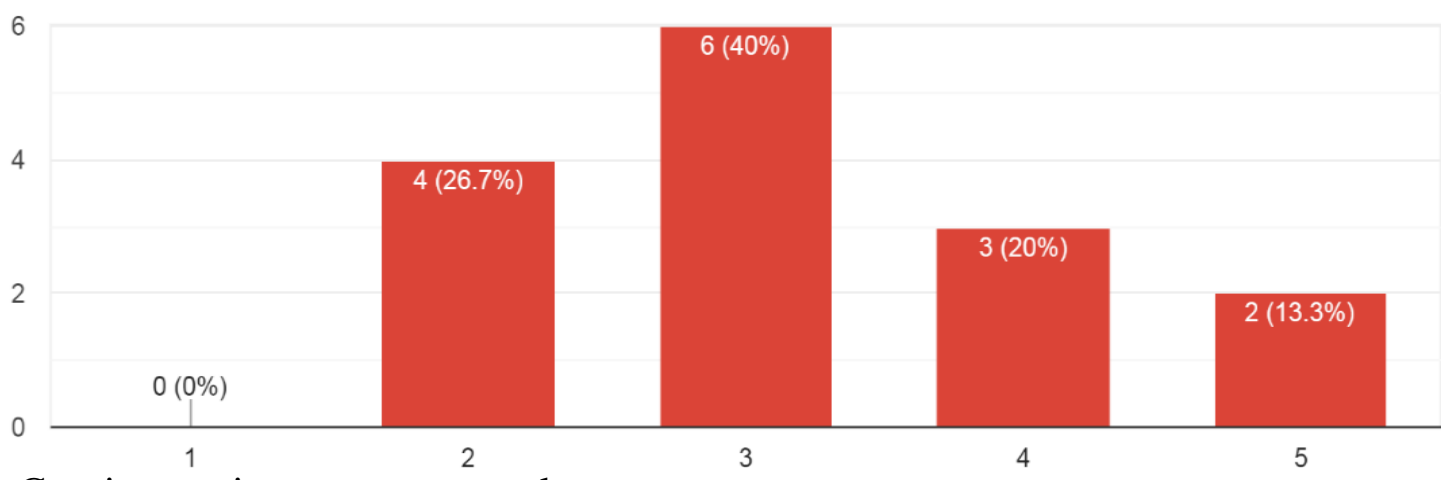

Figure 11. Consistency in assessment results.

21) Assessment measures students “higher-order thinking skills.

15 responses

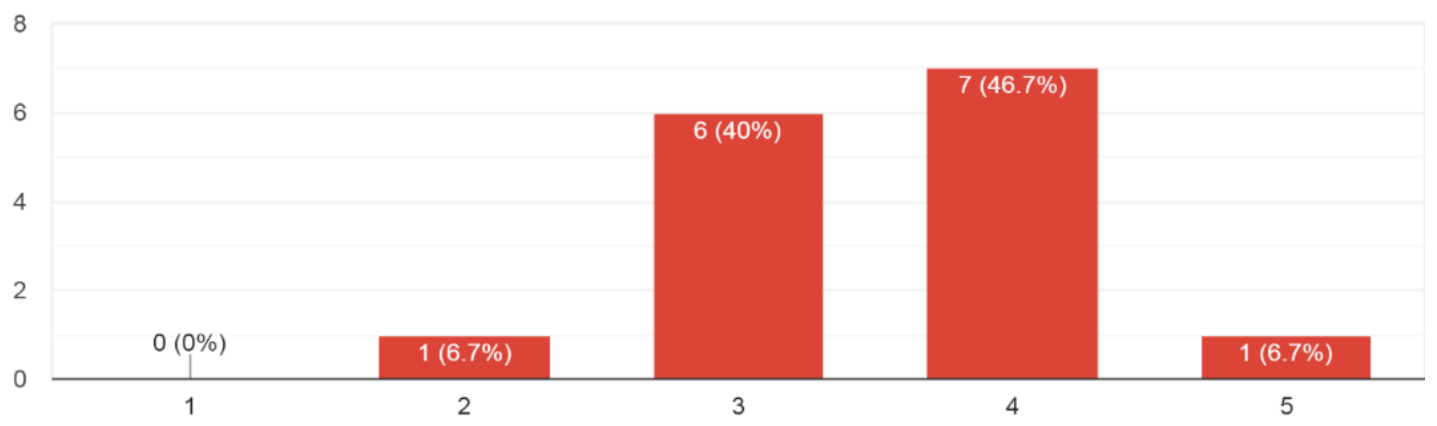

Figure 12. Measurement of students' higher-order thinking skills

22) The assessment helps students improve their learning.

15 responses

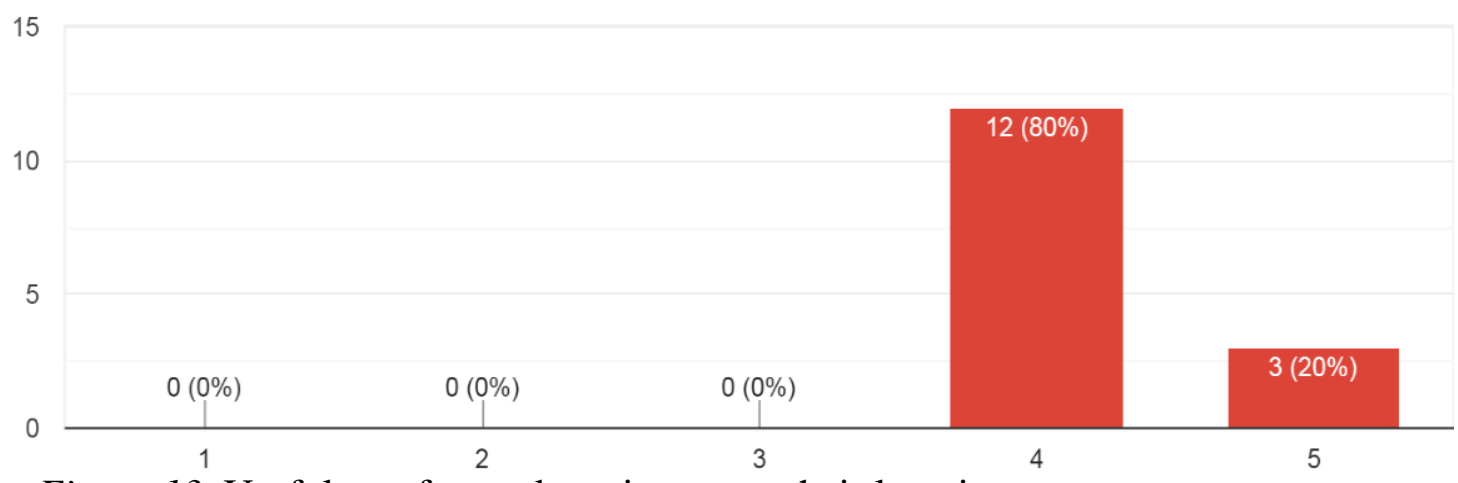

Figure 13. Usefulness for students improves their learning 
23) Assessment allows different students to get different instruction.

15 responses

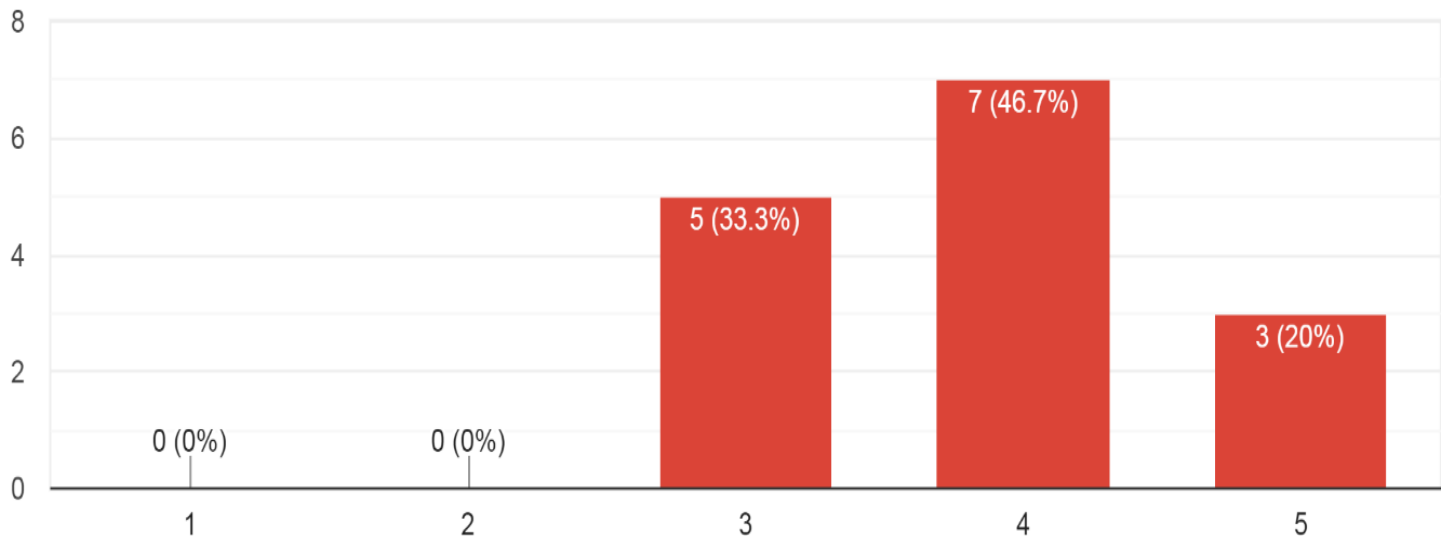

Figure 14. Provision of differentiated instruction to different students

24) Assessment results can be depended on.

15 responses

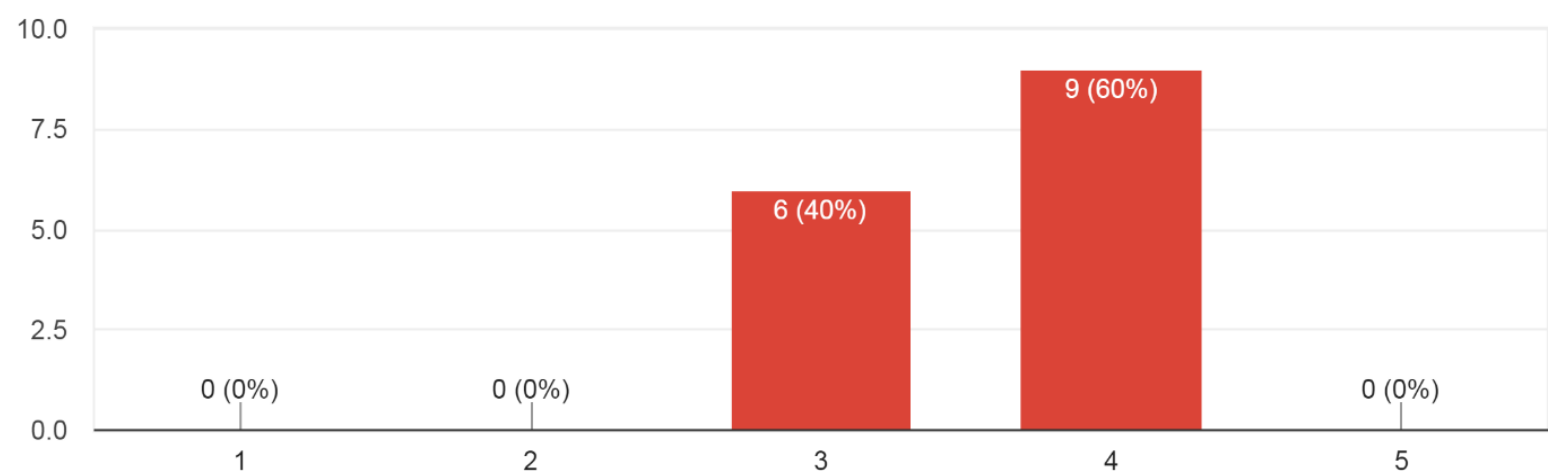

Figure 15. Dependability/ reliability of assessment results

\section{School Accountability}

1) An assessment provides information on how well schools are doing.

15 responses

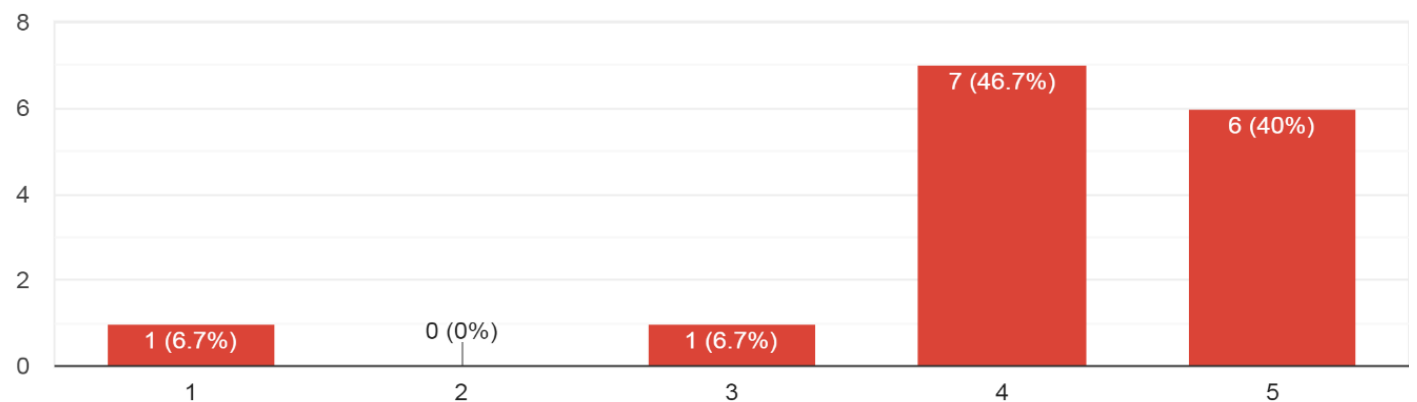

Figure 16. Provision of information on school's performance 
10)Assessment is an accurate indicator of a school 's quality.

15 responses

6

4

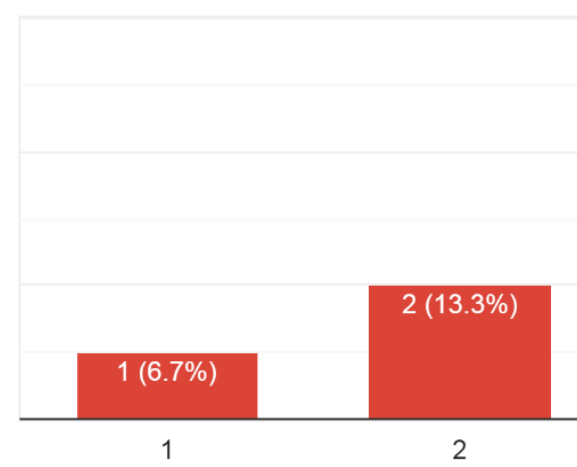

Figure 17. Accurate indicator of a school's quality

19) Assessment is a good way to evaluate a school.

15 responses

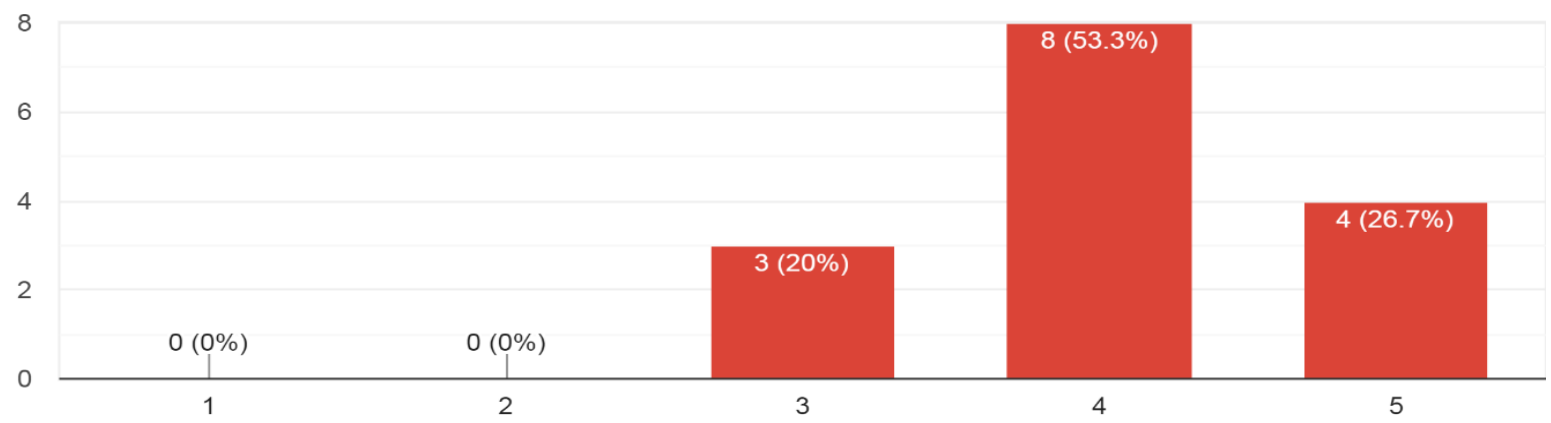

Figure 18. Effective way for school evaluation

Students' Accountability

2) Assessment places students into categories.

15 responses

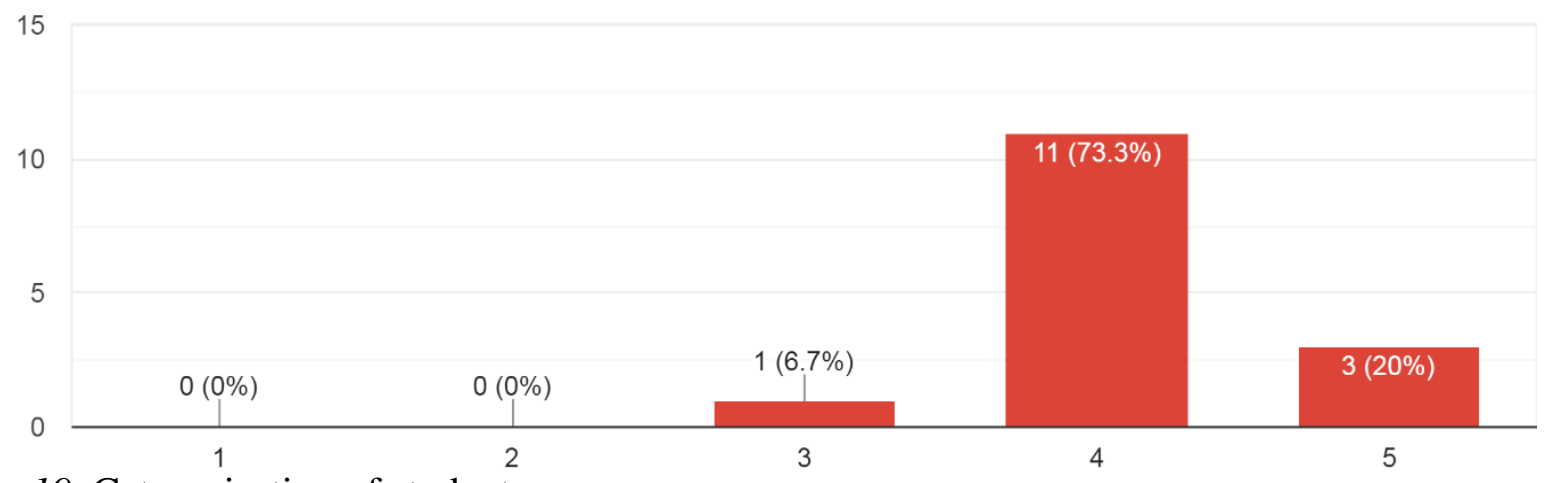

Figure 19. Categorisation of students 
Arab World English Journal (AWEJ) Volume 12. Number 3. September 2021

An Exploratory Study of EFL Teachers' Assessment Conceptions

Qadi

11) Assessment is an accurate indicator of a school 's quality.

15 responses

8

0

$1(6.7 \%)$

$1(6.7 \%)$

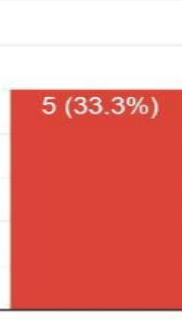

3

Figure 20. An accurate indicator of school quality

20) The assessment determines if students meet qualifications standards

15 responses

15

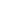

10

$12(80 \%)$

0

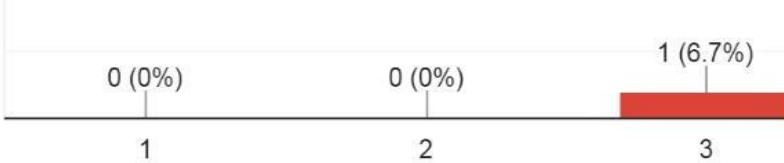

Figure 21. Evaluation of students against qualifications standards Irrelevance Conception

7)Assessment forces teachers to teach in a way against their beliefs.

15 responses

6

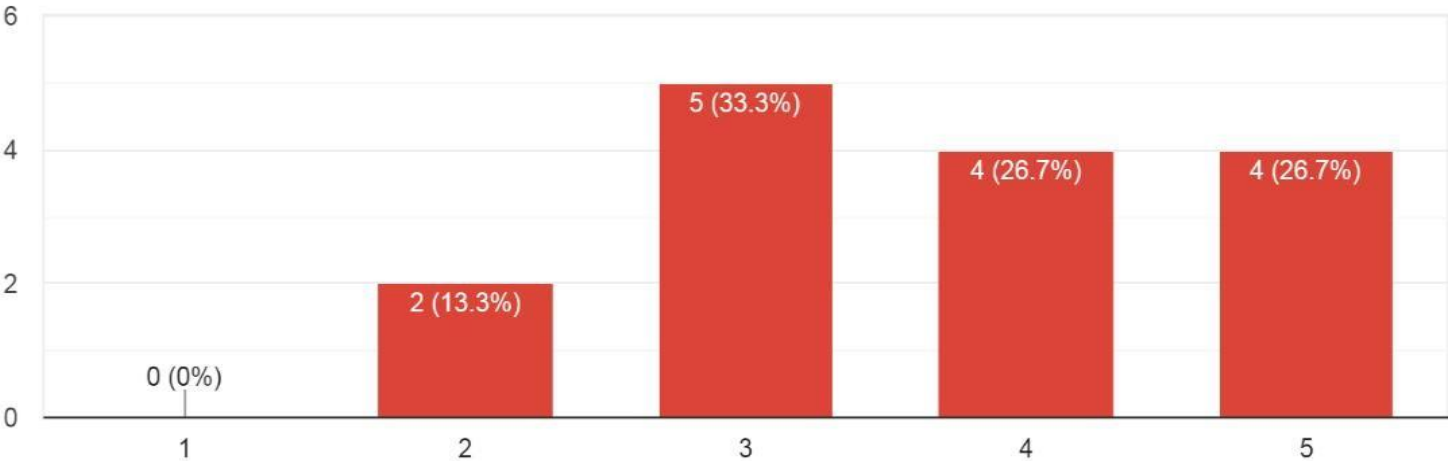

Figure 22. Compulsion on teachers to teach against their beliefs 
8)Teachers conduct assessments but make little use of the results 15 responses

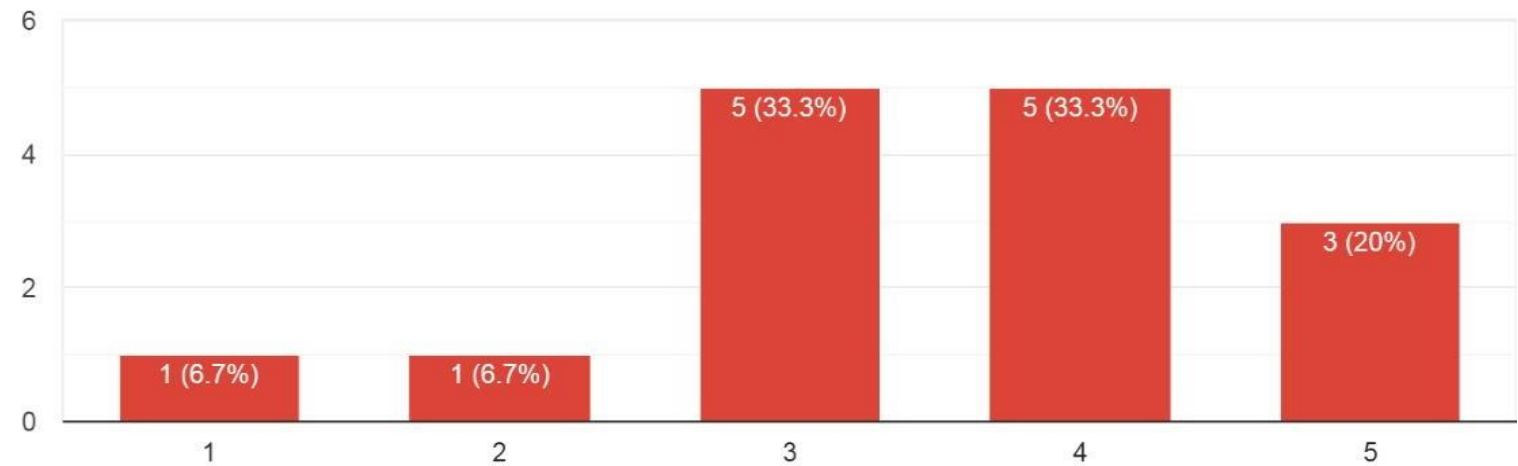

Figure 23. Little use of assessment results by teachers 9)Assessment results should be treated cautiously because of measurement error. ) 15 responses

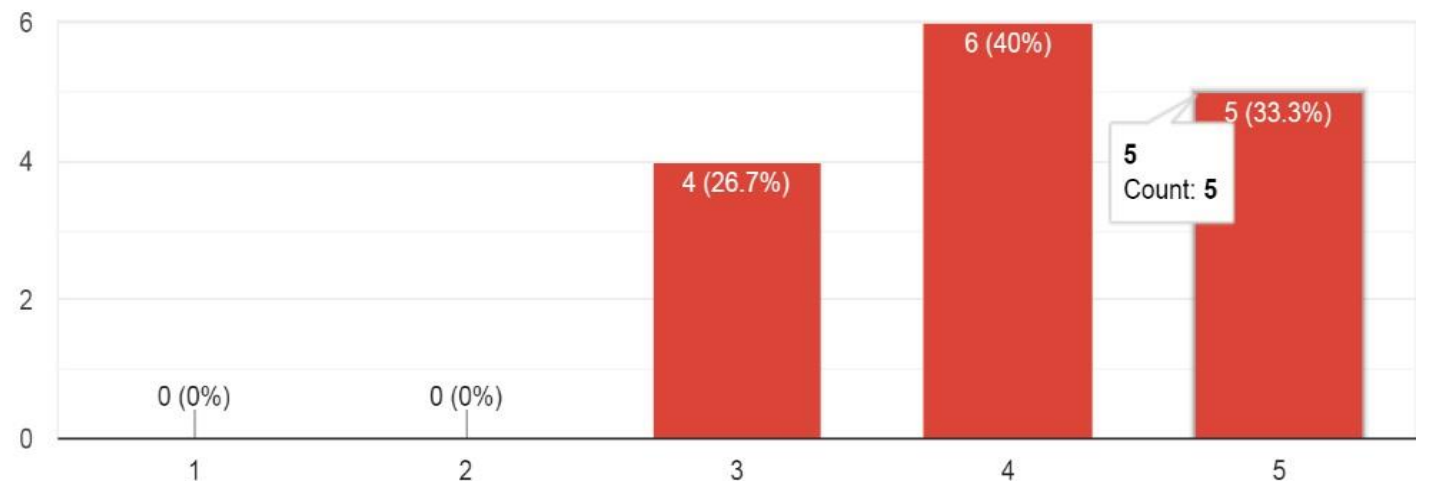

Figure 24. Cautious treatment of assessment results

16) Assessment is unfair to students.

15 responses

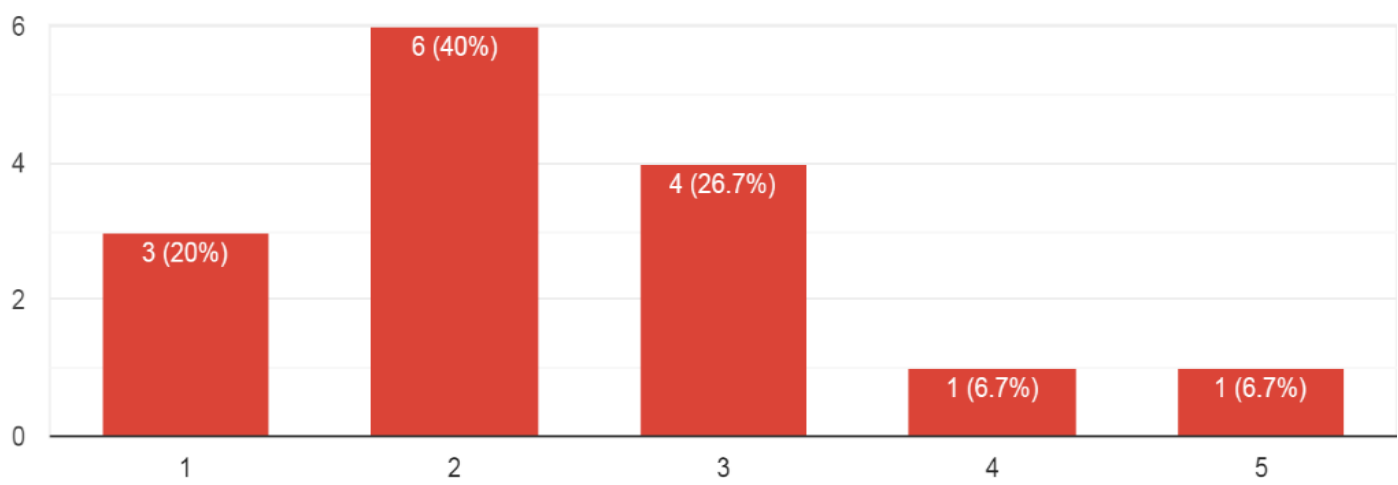

Figure 25. Unfairness of assessment to students 
Arab World English Journal (AWEJ) Volume 12. Number 3. September 2021

An Exploratory Study of EFL Teachers' Assessment Conceptions

Qadi

17) Assessment results are filed \&amp; ignored.

15 responses

6

4

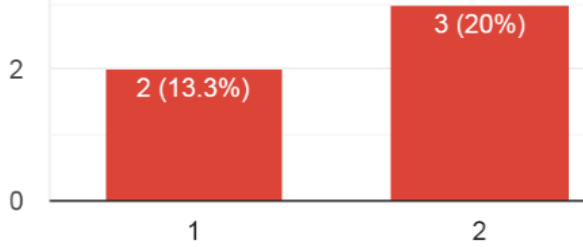

Figure 26. Ignorance of assessment results

18) Teachers should take into account the error and imprecision in all assessment. 15 responses

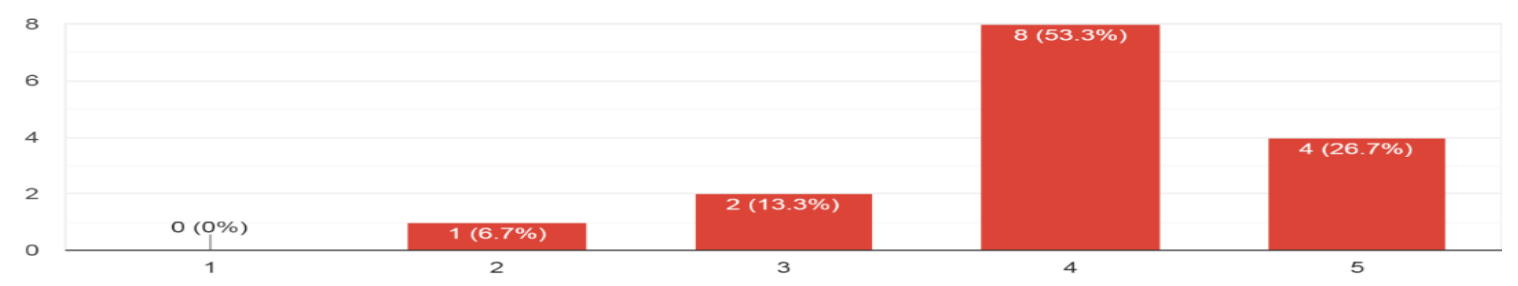

Figure 27. Consideration of error and imprecision in assessment by the teachers

25) Assessment interferes with teaching

15 responses

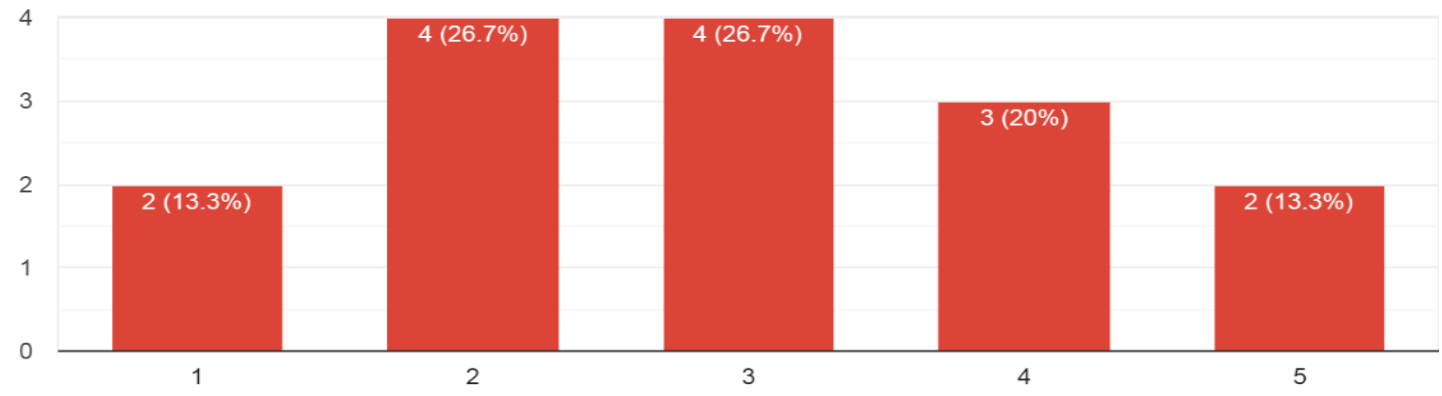

Figure 28. Interference of assessment with teaching 
Arab World English Journal (AWEJ) Volume 12. Number 3. September 2021

26) Assessment has little impact on teaching.

-15 responses

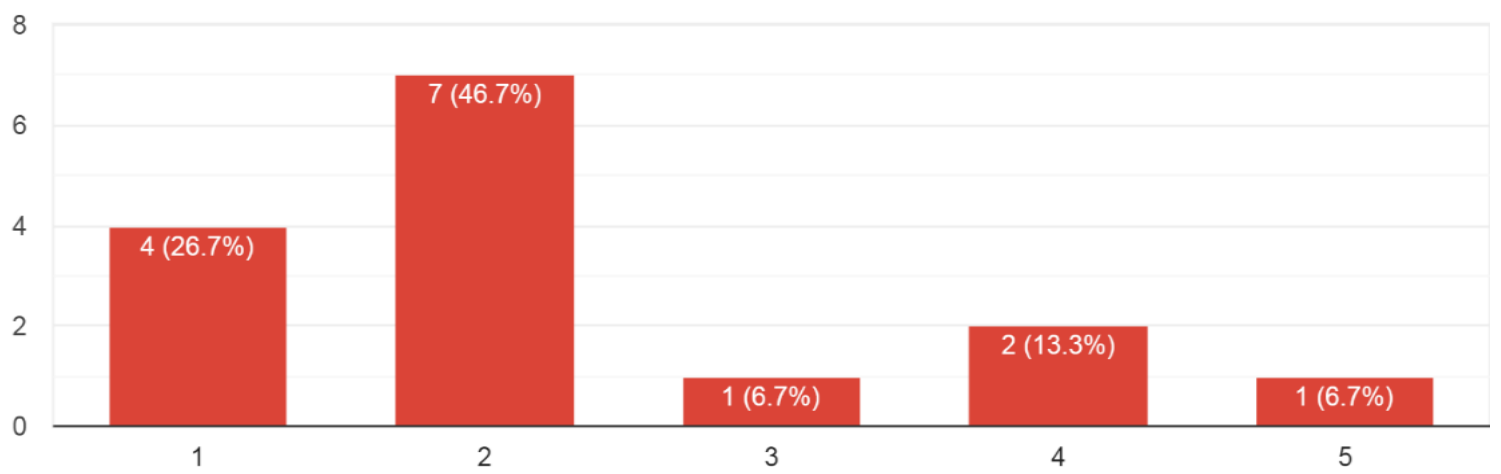

Figure 29. Little impact of assessment on teaching

27) Assessment is an imprecise process.

15 responses

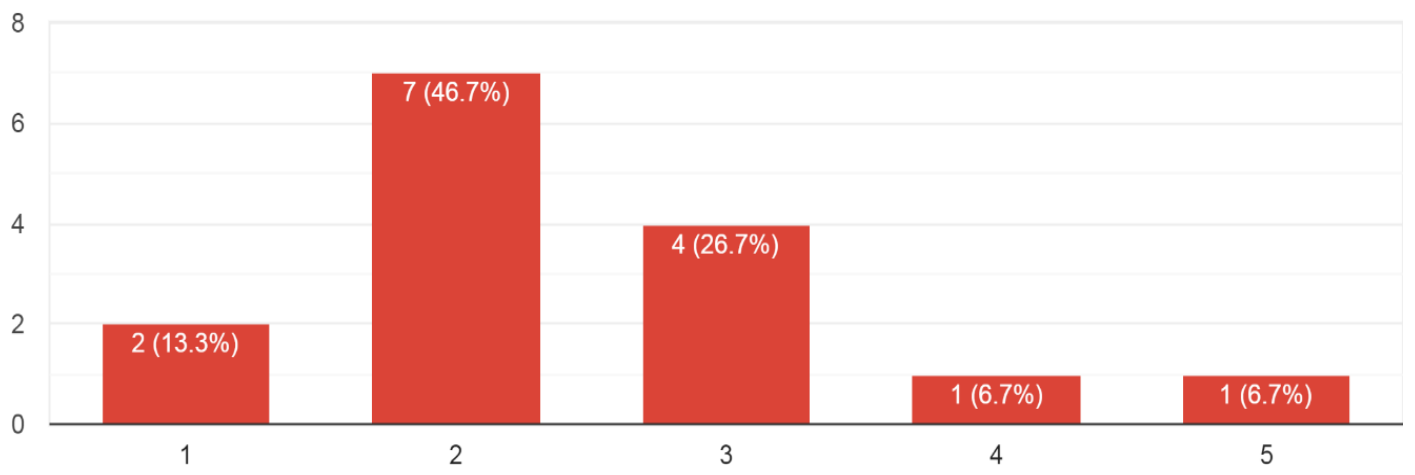

Figure 30. Assessment as an imprecise process

\section{Discussion}

\section{Improvement Conception}

This section comprises 12 Items encompassing twelve sub-factors of the improvement conception. Fifty-three per cent moderately agree, whereas $46.7 \%$ agree that assessment is valuable for assessing how much students have gained from their teachers. Forty-six per cent strongly agree, and $40 \%$ agree that assessment provides students with input on their results, while only $6 \%$ are neutral and 6\% moderately disagree. Out of the total sample, $40 \%$ strongly agree, $40 \%$ agree that assessment is integrated with teaching practice, whereas $20 \%$ are neutral. $46.7 \%$ are neutral, and $46.7 \%$ agree that assessment results are trustworthy, but only $6 \%$ strongly agree. The meagre number of $6.7 \%$ strongly disagree $13 \%$ are neutral whereas $60 \%$ moderately agree and $20 \%$ strongly agree that purpose of assessment is to determine what the students have mastered. Assessment feeds back to students' academic needs, with 53.3\% per cent moderately agreeing and 26.7 per cent strongly agreeing, while $20 \%$ somewhat disagree.

In response to the notion that evaluation data influences continuing student instruction, $53.3 \%$ moderately agree, and 26.7 strongly agree, whereas $13.3 \%$ moderately disagree. The idea assessment results are consistent evokes mixed responses.13.3\% strongly agree, and $20 \%$ 
moderately agree, whereas $40 \%$ are neutral, which is the highest $\%$ so far of neutral response, and 26.7 moderately agree. Forty-six per cent of the population accepts that assessment tests students' higher-order reasoning skills, although $40 \%$ are neutral. Almost all participants, as $20 \%$ strongly agree and $80 \%$ moderately agree that assessment aids students in improving their academic performance. Regarding how assessment allows different students to receive specific guidance, $46.7 \%$ agree, and $20 \%$ strongly agree, whereas $33.3 \%$ are neutral. Regarding assessment outcome dependability, $60 \%$ of respondents responded positively, while $40 \%$ responded neutrally.

\section{School Accountability}

Regarding how reliable information assessment provides on schools' performance, 40\% strongly agree, and 46.7 strongly disagree, whereas only $6.7 \%$ strongly disagree. Considering assessment as an accurate indicator of a school's quality evokes mixed responses as $13.3 \%$ strongly agree, and $40 \%$ moderately agree, whereas $26.7 \%$ are neutral and $13.3 \%$ somewhat disagree, and $6.7 \%$ disagree. Regarding assessment as an excellent way to evaluate a school, $53 \%$ moderately, whereas $26.7 \%$ strongly agree and $20 \%$ are neutral.

\section{Student Accountability}

Given that the assessment divides students into categories, 73.3 per cent moderately agree, 20 per cent strongly agree, and no one disagrees. Forty-six percent approve, 33.3 per cent are neutral, and 6.7 per cent strongly disagree that assigning a grade or level to student work is assessment. (Explain results of 11. Considering the role of assessment in determining whether the students meet qualifications standards, the highest, $80 \%$ moderately agree, and $13.3 \%$ strongly agree, which almost total $94 \%$.

\section{Irrelevance Conception}

The belief that testing pressures teachers to teach in contradictory ways to their values elicits mixed responses, with $26.7 \%$ strongly agreeing and $26 \%$. They somewhat agree, while $33.3 \%$ are rural and just $13.3 \%$ moderately disagree. The conception that teachers perform tests but do not use the findings elicits uneven responses, with $20 \%$ firmly agreeing, $33.3 \%$ agreeing mildly, $33.3 \%$ favourable, and $6.7 \%$ disagreeing. $33.3 \%$ agree firmly, $40 \%$ agree mildly, and $26.7 \%$ disagree. Most of the teachers, $60 \%$, deny that appraisal is unjust to pupils, while 26.7 are neutral. The belief that assessment outcomes are filed and overlooked gets no simple answer, as $40 \%$ of respondents are unsure, with almost identical numbers agreeing and disagreeing.

Nearly $80 \%$ of teachers believe that teachers should allow for mistakes and imprecision in all tests, while $13.3 \%$ of the participants were neutral. The notion that assessment interferes with teaching elicits insightful findings, with approximately 33\% agreeing, 40\% disagreeing, and $26.7 \%$ neutral. There is an $83 \%$ disagreement and $19 \%$ consensus that appraisal does not affect teaching. Regarding assessment being an imprecise procedure, $60 \%$ agree, $26 \%$ disagree, and only a few people disagree.

\section{Conclusion}

The beliefs and practices of teachers have a significant impact on how educationists use evaluation methods. Teachers' conceptions shape their preferences much more powerfully and 
effectively than their school experience and context. Therefore, figuring out what they believe is essential to tailor their wisdom to educational policies and requirements. Even though most researchers researched evaluation concepts internationally, we find a scarcity of such research in Saudi Arabia in general and the English Language Center, Afaq University, in particular. The present research explores EFL teachers' evaluation views in the present context to and identifies how their perceptions might efficiently and significantly impact their assessment practices.

According to the findings, school and student accountability played a significant role in EFL teachers' evaluation conceptions at IIU. The educational system's competitive nature, in which highstakes assessments play a vital role in developing students' future, and the educationists grade schools from most successful to least successful, may support this theory. However, improvement had the highest consensus of all the conception levels, showing that EFL teachers at ELC are willing to use evaluation to enhance their teaching and learning processes. As a result, textbooks, assessment procedures, and other materials should be standardised and updated following student and school accountability. The findings demonstrated that teachers' perceptions of irrelevance had not changed, and they still believed in it. As a result, during the undergraduate education process, all teacher applicants should take various assessment-related courses. Nevertheless, apart from competency accountability and related tasks, both books and lecturers can present assessment more extensively so that EFL teachers at the English Language Center, Afaq Qura University, Saudi Arabia, could truly understand and accept it as a crucial driver for success instead of a burden.

\section{Suggestions for Further Research}

Due to a paucity of time, the current study only included 15 teachers; however, future studies should extend this study to include other participants from other universities, including female teachers, and triangulate the survey approach with an interview.

\section{About the author:}

Ahmad Qadi is an assistance professor of English language and translation at Umm Al-Qura University, Makkah, Saudi Arabia. He has a $\mathrm{PhD}$ in translation and linguistics from Western Sydney, Australia. He also has MA in linguistics and translation. His research interests include English language teaching pedagogies, translation, flipped learning and ELT assessment practices. ORCID number: 0000-0002-1169-5851

\section{References}

Azis, A. (2015). Conceptions and practices of assessment: A case of teachers representing improvement conception. TEFLON Journal - A publication on the teaching and learning of English, 26(2), 129. https://doi.org/10.15639/teflinjournal.v26i2/129-154

Badders, W. (2000). Methods of Assessment. (H. M. Company, Ed.) Retrieved from http://www.eduplace.com/science/profdev/articles/badders.html.

Barnes, N., Fives, H., \& Dacey, C. M. (2017). U.S. teachers' conceptions of the purposes of assessment. Teaching and Teacher Education, 65, 107-

116. https://doi.org/10.1016/j.tate.2017.02.017

Black, P., \& Wiliam, D. (2006). Developing a theory of formative assessment. In J. Gardner (Ed.), Assessment and Learning (p. 206-230). London, England: Sage. 
Brown, G. T. (2004). Teachers' conceptions of assessment: Implications for policy and professional development. Assessment in Education: Principles, Policy \& Practice, 11(3), 301-318. https://doi.org/10.1080/0969594042000304609

Brown, G. T. (2006). Teachers' conceptions of assessment: Validation of an abridged version. Psychological Reports, 99(1), 166-170. https://doi.org/10.2466/pr0.99.5.

Brown, G. T. (2008). Conceptions of assessment: Understanding what assessment means to teachers and students. New York, NY: Nova Science Publishers.

Brown, G. T., Kennedy, K. J., Fok, P. K., Chan, J. K., \& Yu, W. M. (2009). Assessment for student improvement: Understanding Hong Kong teachers' conceptions and practices of assessment. Assessment in Education: Principles, Policy \& Practice, 16(3), 347363. https://doi.org/10.1080/09695940903319737

Brown, G. T., \& Michaelides, M. P. (2010). Ecological rationality in teachers' conceptions of assessment across samples from Cyprus and New Zealand. European Journal of Psychology of Education, 26(3), 319-337. https://doi.org/10.1007/s10212-010-0052-3

Brown, G. T., \& Remesal, A. (2012). Prospective teachers' conceptions of assessment: A crosscultural comparison. The Spanish journal of psychology, 15(1),7589. https://doi.org/10.5209/rev_sjop.2012.v15.n1.37286

Brown, G. T., \& Remesal, A. (2017). Teachers' conceptions of assessment: Comparing two inventories with Ecuadorian teachers. Studies in Educational Evaluation, 55, 6874. https://doi.org/10.1016/j.stueduc.2017.07.003

Brown, H. D., \& Abeywickrama, P. (2010). Language assessment: Principles and classroom practices. Pearson Longman.

Danielson, C. (2008). Assessment for learning: For teachers as well as students. In C. A. Dwyer (Ed.), The future of assessment: Shaping teaching and learning (pp. 191-213). New York: Taylor \& Francis.

Gebril, A. (2016). Language teachers' conceptions of assessment: An Egyptian perspective. Teacher Development, 21(1), 81-100. https://doi.org/10.1080/13664530.2016.1218364

Gonzales, G. C. (2003). Assessment in English language classrooms: Constructing and empowering meaningful learning. Revista Pensamiento Actual, 4(5), 84-92. https://revistas.ucr.ac.cr/index.php/pensamiento-actual/article/download/8312/7867/

Gore, J. M., Griffiths, T., \& Ladwig, J. G. (2004). Towards better teaching: Productive pedagogy as a framework for teacher education. Teaching and Teacher Education, 20(4), 375-387. https://doi.org/10.1016/j.tate.2004.02.010

Erwin, T. D. (1991). Assessing student learning and development: A guide to the principles, goals, and methods of determining college outcomes. Jossey-Bass

Harris, L. R., \& Brown, G. T. (2009). The complexity of teachers' conceptions of assessment: Tensions between the needs of schools and students. Assessment in Education: Principles, Policy \& Practice, 16(3), 365- 381. https://doi.org/10.1080/09695940903319745

Li, W. S., \& Hui, S. K. F. (2007). Conceptions of Assessment of mainland China college lectures: A technical paper analysing the Chinese version of COA-III. The Asia PacificEducation Researcher, 16(2), 185-198. https://doi.org/10.3860/taper.v16i2.262

Moiinvaziri, M. (2015). University teachers' conception of assessment: A structural equation modelling approach. Journal of Language, Linguistics and Literature, 1(3), 75-85. http://files.aiscience.org/journal/article/pdf/70360010.pdf 
Mustafa, M. B., \& Manaf, U. K. (2019). Educators' conception of student assessment and their practices in an institution of education in MARA. International Journal of Academic Research in Business and Social Sciences, 9(10) 292-300. https://doi.org/10.6007/ijarbss/v9-i10/6492

Opre, D. (2015). Teachers' conceptions of assessment. Procedia - Social and Behavioral Sciences, 209, 229-233. https://doi.org/10.1016/j.sbspro.2015.11.222

Pajares, M. F. (1992). Teachers' beliefs and educational research: Cleaning up a messy construct. Review of Educational Research, 62(3), 307- 332. https://doi.org/10.3102/00346543062003307

Stiggins, R. J. (1988). Revitalising classroom assessment: The highest instructional priority. Phi Delta Kappan, 69(5), 363-368. http://www.jstor.org/stable/20403636

Trotter, E. (2006). Student perceptions of continuous summative assessment. Assessment \& Evaluation in Higher Education, 31(5), 505- 521. https://doi.org/10.1080/02602930600679506

Vardar, E. (2010). Sixth, Seventh and Eighth Grade Teachers' Conceptions of Assessment (Unpublished master's thesis). Middle East Technical University Graduate School of Social Sciences, Ankara.

Yetkin, R. (2018). Exploring pre-service teachers' conceptions of assessment in the Turkish context. European Journal of Education Studies, 4(5), 133-147. https://doi.org/10.5281/zenodo.1230554

Yetkin, R., \& Ozer, Z. (2020). An Investigation into In-service and Pre-service English Teachers' Conception of Assessment. Journal of Theoretical Educational Science, 13(2), 384-396. https://doi.org /10.30831/akukeg.5828 